\title{
EDITORIAL
}

\section{5 anos fazendo profissão a partir de uma ciência sólida}

\section{5 years of phycologist coming from a solid science}

Profa. TÂnia Elena Bonfim Editoria Associada Revista Psicólogo InFORMaÇÃo

É com enorme satisfação que esse periódico vem ao público numa edição exclusivamente comemorativa dos 45 anos do nascimento do Curso de Graduação em Psicologia na Universidade Metodista de São Paulo.

Essa edição busca, além de comemorar um curso de graduação que fora instalado e delineado entre os primeiros cursos de Psicologia no Brasil, trazer ao público recortes dessa história tão importante para a criação e desenvolvimento da Psicologia como Profissão no país.

Reativar algumas lembranças desde seu nascimento no início dos anos 1970 e seguir com essa história até os dias atuais, além de enaltecer a profissão, vem essa edição de PSICÓLOGO INFORMAÇÃO. Brinda esse momento com gratidão aos seus idealizadores, seus gestores, seus professores e seus funcionários, bem como a todas as pessoas que fizeram e fazem esse curso continuar assentado numa ciência sólida e que se desenvolve revendo verdades, mudando paradigmas, mas nunca deixando sua seriedade, compromisso e ética com o ser humano. 
Quero ainda expressar meu afeto e respeito para com todos os alunos que passaram pela Psicologia Metodista e aqueles que aqui estão, pois esta história só pôde e pode ser construída tendo-os como propósito. E, igual a esses estudantes e psicólogos que aqui se fizeram, também aproveito dessa oportunidade para, pessoalmente, agradecer a essa instituição que me acolheu como aluna e depois como profissional. Sinto-me feliz por também fazer parte dessa história!

Essa edição abre-se com o texto elaborado pelo Prof. Péricles de Oliveira Prado Filho que se intitula "Nascimento do Curso de Psicologia na Metodista: reminiscências dos anos 1971 a 1975". O autor, primeiro coordenador do curso e engajado em sua criação e ajustes iniciais, destaca-se entre os primeiros psicólogos brasileiros, ou seja, aqueles que se formaram Psicólogos já dentro de uma formação específica; isto pois, tal como relembra o próprio autor, foi na década de 1960 que se iniciou a formação do Psicólogo no Brasil uma vez que até então esses profissionais eram formados em outras áreas, como Filosofia, educação. Neste texto, é com entusiasmo que o Prof. Péricles relembra sua trajetória como docente-psicólogo, e costura, ao mesmo tempo, o nascimento de um curso que na época preocupou-se em se instalar sobre numa base científica sólida, mas que garantisse ao psicólogo sua posição na então classificação brasileira de ocupações. Descreve ainda o autor, a grande preocupação, na ocasião, com a integração entre os conteúdos e temas curriculares, as inter-relações com instituições já existentes e com o ainda incipiente Conselho Regional de Psicologia. Deste modo, esse texto é um importante convite para o leitor interessado na origem da profissão de psicólogo não só em nossa micro região do $\mathrm{ABC}$ paulista, mas também no Brasil.

Buscando remontar a história do curso de Graduação em Psicologia na Metodista, temos o segundo texto de autoria da Profa. Mariantonia Chíppari "Fragmentos de uma História: assim tudo começou ...... E ainda continua". Nesse texto a professora traça, de forma técnica e cuidadosa, o percurso histórico do curso de Psicologia e descreve criteriosamente cada período e cada momento em que houve conservação e mudanças. No texto, a autora procura enfatizar como o Curso de Graduação em Psicologia procurou conservar vários elementos da tradição e da solidez científica, e em 
que momentos e como as modificações foram necessárias de modo a sempre considerar as transformações da realidade social brasileira, bem como aquela realidade regional em que está inserida.

O terceiro texto, de autoria da Profa. Marília Martins Vizzotto intitulado: "Psicologia na Universidade Metodista : um recorte da história" faz também um recorte da história do curso de psicologia na Metodista, mas se atém a um período que vai de 1990 até 2001, pois, além da autora ter coordenado o curso e dirigido a faculdade, foi nesse período em que o Instituto Metodista passa a ser a Universidade Metodista de São Paulo e o curso de Psicologia sofre grandes transformações a partir das discussões das "Novas Diretrizes Curriculares" para os cursos de graduação no Brasil e ganha o status de faculdade, agregando-se nessa nova estrutura, a pós-graduação em psicologia e a graduação em fonoaudiologia. A autora também procura fazer algumas críticas ao atual modelo de ensino superior brasileiro que sofre grandes modificações justamente nesse mesmo período e se arrisca em considerar o quanto esse "novo" modelo de ensino, tanto público quanto privado atravessa um período histórico e social com grandes desafios!

O quarto texto, de autoria da professora Olímpia Rosa Noronha que vem com o título "UMESP/ Psicologia 45 anos... e 40 anos meus nesta Instituição" também segue essa linha de raciocínio em que se juntam a trajetória do professor e trajetória do próprio curso. A autora narra com entusiasmo e afetividade sua estada na instituição, sua chegada ainda nos anos setenta, seu início em sala de aula e seu percurso como supervisora de estágios em psicologia clínica. Descreve ainda o quanto seu "furor" pelo conhecimento e entusiasmo pela psicologia e pela psicanálise a fizeram, paralelamente, ingressar e fazer sua formação em Psicanálise na Sociedade Brasileira de Psicanálise de São Paulo. Bravamente a nossa querida mestre permanece na instituição! Além de completar toda sua formação, a autora, parafraseando Bion, mostra como foi interessante "Aprender com a experiência". O texto da professora é um convite ao leitor para esse aprecie uma narrativa entusiasmada e afetiva da psicóloga que inicia e constrói essa história há quarenta anos!

O próximo artigo, de autoria de nossa querida professora, hoje aposentada, Profa. Maria Helena Bekers, intitula-se "Escrevendo no diário ou, ensinando, aprend...." traz recortes de sua trajetória 
como psicóloga-professora, que ingressa na instituição para lecionar psicologia e permanece nela por 30 anos. Maria Helena narra, de maneira leve e poética, um interessante período inicial de sua carreira, quando ainda a jovem psicóloga chega a São Paulo e ingressa num trabalho novo, numa cidade ainda desconhecida, numa instituição ainda desconhecida e dedica-se ao ensino de psicologia concomitantemente à adaptação de viva que faz. Descreve seus "compassos" e "descompassos", a espera pela vinda de seu noivo (nosso também querido Prof. Johannes Petrus Maria Bekers), sua adaptação e sua construção de vínculos. Convidamos o leitor a se inteirar com o texto da professora que em todo seu conteúdo expressa seu prazer em ensinar e aprender como duas ações concomitantes.

Fechando essa edição, também convidamos os leitores a apreciarem o artigo da professora Sueli Rossini que se intitula: “ $D a$ Idealização à Identificação: memórias afetivas em uma trajetória no Instituto Metodista de Ensino Superior". Também de maneira bastante afetiva a essa docente faz uma narrativa trazendo suas memórias de fatos objetivos e subjetivos, vivenciados na Metodista dos anos oitenta. A autora traz ao texto suas experiências acadêmicas e outras experiências de vida do cotidiano, da realidade externa do campus no Instituto Metodista de Ensino Superior. Assim, ao descrever essa trajetória a professora compreende, com auxílio da literatura psicanalítica como a instituição - em suas vivencias e seus cenários, tivera sua importância nas suas representações psíquicas.

Assim convidamos professores, estudantes e todos os leitores interessados em conhecer um pouco mais da história da Psicologia na Metodista de São Paulo, na região do ABC paulista e também no Brasil, pois elas se confundem e se misturam. Além do que, é interessante conhecer como esses professores pioneiros deixaram aqui seus trabalhos, seus empenhos, suas distinções, que hoje brindamos e enaltecemos.

Por fim, quero também lembrar outro querido professor brasileiro - Paulo Freire, do qual tomo suas palavras:

“Educação não transforma o mundo ...... Educação muda pessoas ........ Pessoas transformam o mundo".

Parabéns Psicologia!! 